\title{
Phorbol Ester Restores L-System Amino Acid Transport of B Lymphocytes in Chronic Lymphocytic Leukemia
}

\author{
Timothy J. Woodlock, George B. Segel, and Marshall A. Lichtman \\ Departments of Medicine, Pediatrics, and Biophysics, University of Rochester School of Medicine, Rochester, New York 14642
}

\begin{abstract}
L (leucine-favoring)-system amino acid transport is uniquely and selectively diminished in chronic lymphocytic leukemia B lymphocytes: the maximal velocity of transport is $10 \%$ of normal B lymphocytes. We examined L-system transport in chronic leukemic B lymphocytes after incubation with tetradecanoyl phorbol acetate to determine if the transport abnormality can be corrected by the apparent cell maturation induced by this agent. Amino acid uptake was measured using 2-amino-2carboxy-bicycloheptane, an L-system specific synthetic amino acid. Marked enhancement of $L$-system transport occurred in each of 12 leukemic cell populations; the initial velocity of transport in phorbol ester-treated cells increased 8-fold and 14-fold at 16 and $40 \mathrm{~h}$, respectively, compared with untreated cells. The $V_{\max }$ of the $L$-system in phorbol ester-treated leukemic cells was similar to that of phorbol ester-treated normal B lymphocytes. The L-system enhancement of the leukemic cells paralleled the development of plasmacytoid features at $\mathbf{4 0}$ h. Uptake of leucine, a naturally occurring L-system amino acid, was also increased by tetradecanoyl phorbol acetate. $\mathbf{C y}$ cloheximide, $100 \mu \mathrm{g} / \mathrm{ml}$, which inhibited over $90 \%$ of protein synthesis in phorbol ester-treated chronic leukemic cells, blocked completely the phorbol ester-induced L-system enhancement. Phorbol ester treatment restores the selective $L$ system transport defect in chronic lymphocytic leukemia B lymphocytes, and this process coincides with in vitro maturation of the leukemic cells.
\end{abstract}

\section{Introduction}

Chronic lymphocytic leukemia (CLL) ${ }^{1}$ is characterized by the proliferation and accumulation of immature lymphocytes. These cells are thought to be arrested at the early $B$ and intermediate B lymphocyte stages of normal B cell maturation as

This material was presented in part at the Annual Meeting of the American Society of Hematology, 8 December, 1986.

Address reprint requests to Dr. Segel, University of Rochester Medical Center, 601 Elmwood Ave., Box 610, Rochester, NY 14642. 1987.

Received for publication 22 April 1987 and in revised form 7 July

1. Abbreviations used in this paper: A-, alanine favoring; ASC-, alanine-serine-cysteine; $\mathrm{BCH}$, 2-amino-2-carboxy-bicyclo(2,2,1)-heptane; CLL, chronic lymphocytic leukemia; $K_{\mathrm{u}}$, constant for nonsaturable uptake; L-, leucine favoring; methyl-AIB, 2-(methylamino) isobutyric acid; TC-199, tissue culture medium 199; TPA, tetradecanoyl phorbol acetate; $V_{\mathrm{i}}$, initial velocity of amino acid transport.

J. Clin. Invest.

(c) The American Society for Clinical Investigation, Inc.

0021-9738/88/01/0032/07 \$2.00

Volume 81, January 1988, 32-38 judged by monoclonal antibody reactivity to their surface antigens and by the type and location of immunoglobulin (1). CLL cells have two well-characterized nonimmunologic cell membrane abnormalities: absent or diminished 5'-nucleotidase activity in most patients studied (2) and markedly diminished $\mathrm{L}$ (leucine-favoring)-system amino acid uptake $(3,4)$. The $V_{\max }$ of L-system transport in fresh CLL cells is $10 \%$ of normal blood B lymphocytes and is also significantly lower than tonsillar B lymphocytes, blood T lymphocytes, and a B cell line (Table I). Uptake by the A (alanine-favoring)- and ASC (alanine-serine-cysteine)-systems, the two other major amino acid transport systems in mammalian cells, is normal in CLL cells as compared with other lymphocyte types (4).

Maturation of CLL B cells to a plasmacytoid phenotype can be induced in vitro by treatment with tetradecanoyl phorbol acetate (TPA) (5-7). Plasmacytoid morphology and increased cytoplasmic immunoglobulin concentration are noted at $48 \mathrm{~h}(5)$, and immunoglobulin secretion occurs after longer TPA exposure $(6,7)$. We have examined the kinetics of L-system amino acid transport in CLL B lymphocytes after treatment with TPA and have found marked enhancement of Lsystem transport with uptake velocities comparable with those found in TPA-treated normal B lymphocytes.

\section{Methods}

Preparation of lymphocytes. CLL lymphocytes were obtained from the blood of chronic leukemia patients with stable disease; 10 out of the 12 patients studied had not received chemotherapy, and the remainder had not been treated in the previous 6 mo. Platelets were removed by centrifugation at $160 \mathrm{~g}$ for $15 \mathrm{~min}$ and aspiration of the platelet-rich supernatant fraction. The remaining buffy coat was suspended in 100 $\mathrm{ml}$ of tissue culture medium 199 (TC-199) containing $1 \% \mathrm{wt} / \mathrm{vol}$ BSA and $5 \mathrm{ml}$ of packed sheep red blood cells pretreated with 2-aminoethylisothiouronium bromide. The suspension was incubated at $37^{\circ} \mathrm{C}$ for $30 \mathrm{~min}$, followed by centrifugation over Ficoll-metrizoate as previously described (4). T lymphocyte-sheep cell rosettes sedimented with the granulocytes below the Ficoll-metrizoate, and purified CLL B lymphocytes were harvested from the supernate-Ficoll interface. Cells were washed twice in TC-199, and resuspended in RPMI 1640 medium containing $20 \% \mathrm{vol} / \mathrm{vol}$ heat-inactivated bovine calf serum at a density of $2 \times 10^{6}$ lymphocytes $/ \mathrm{ml}$. The cell phenotype was determined using an Epics $C$ flow cytometer (Coulter Electronics Inc., Hialeah, FL) with fluorescent monoclonal antibodies against B4, a B lymphocyte determinant; Leu 4, a T lymphocyte determinant; and Leu 1, a surface antigen found on normal T lymphocytes and CLL B lymphocytes, but absent from normal B lymphocytes (8). The final cell suspensions contained $96 \%$ CLL B lymphocytes and $4 \%$ residual T lymphocytes.

Normal blood B lymphocytes were prepared from the plateletpheresis residues of healthy blood donors (9). Lymphocytes and monocytes were isolated by step gradient centrifugation over Ficoll-metrizoate, washed once in TC-199, and separated by countercurrent centrifugal elutriation (10). Aliquants containing $>98 \%$ lymphocytes were separated into $B$ and $T$ cell fractions using a nylon wool adherence technique (11). A $60-\mathrm{ml}$ polypropylene syringe was used as a 
Table I. $V_{\max }$ of L-System Transport in CLL and Normal B Lymphocytes

\begin{tabular}{lllll}
\hline $\begin{array}{l}\text { CLL } \\
\text { B lymphocytes }\end{array}$ & $\begin{array}{l}\text { Blood } \\
\text { B lymphocytes }\end{array}$ & $\begin{array}{l}\text { Tonsillar } \\
\text { B lymphocytes }\end{array}$ & $\begin{array}{l}\text { Blood } \\
\text { T lymphocytes }\end{array}$ & $\begin{array}{l}\text { B cell line } \\
\text { (RPMI 1788) }\end{array}$ \\
\hline $103(10)$ & $1029(6)$ & $840(2)$ & $969(3)$ & $900(1)$
\end{tabular}

The data represent the mean measurements from the number of cell populations shown in parentheses. The $V_{\max }$ is expressed as micromoles per liter cell water per minute (4).

column and packed with $2.4 \mathrm{~g}$ nylon wool compacted to a volume of $24 \mathrm{ml}$ with the syringe plunger. The column was heat sterilized and washed with $150 \mathrm{ml}$ of TC-199 containing $5 \% \mathrm{vol} / \mathrm{vol}$ bovine calf serum at $37^{\circ} \mathrm{C}$. A $10-\mathrm{ml}$ cell suspension containing $4 \times 10^{7}$ lymphocytes/ml in TC-199 with $10 \% \mathrm{vol} / \mathrm{vol}$ bovine calf serum was washed into the nylon wool using an additional $5 \mathrm{ml}$ of media. The column was sealed and incubated at $37^{\circ} \mathrm{C}$ for $45 \mathrm{~min}$ to allow adherence of the B lymphocytes. The nonadherent $T$ lymphocytes were eluted from the column with $50 \mathrm{ml}$ of media followed by an additional wash of $250 \mathrm{ml}$ of media. The adherent B lymphocytes were eluted by teasing the nylon wool with sterile forceps and forcibly expelling media from the column using the syringe plunger. Cells were resuspended in RPMI 1640 medium containing $20 \% \mathrm{vol} / \mathrm{vol}$ heat-inactivated bovine calf serum at a density of $2 \times 10^{6} \mathrm{lymphocytes} / \mathrm{ml}$. This procedure yielded $5 \times 10^{7}$ B lymphocytes. The percent B lymphocytes in both B and T cell fractions was determined by quantifying the number of surface immunoglobulin positive cells with a fluorescein-labeled anti-human Ig antibody using a Nikon Fluophot microscope. The adherent B cell fractions contained $85 \%$ B lymphocytes with $15 \%$ residual $T$ lymphocytes.

Lymphocytes were cultured in RPMI 1640 medium containing $20 \% \mathrm{vol} / \mathrm{vol}$ heat-inactivated bovine calf serum at $37^{\circ} \mathrm{C}$ in a humidified incubator with $5 \% \mathrm{CO}_{2}$. Penicillin, $100 \mathrm{U} / \mathrm{ml}$, streptomycin, 100 $\mu \mathrm{g} / \mathrm{ml}$, gentamicin, $40 \mu \mathrm{g} / \mathrm{ml}$, and amphotericin B, $0.25 \mu \mathrm{g} / \mathrm{ml}$, were present in each flask. TPA (Sigma Chemical Co., St. Louis, MO) was dispensed from a $0.3-\mathrm{mM}$ stock solution in DMSO to a final concentration of $0.15 \mu \mathrm{M}$ in treated samples. Cycloheximide (CalbiochemBehring Corp., La Jolla, CA) was dispensed from a $10-\mathrm{mg} / \mathrm{ml}$ stock solution in distilled water to a final concentration of $100 \mu \mathrm{g} / \mathrm{ml}$ in treated samples.

Pathways of amino acid uptake. The L-, A-, and ASC-systems of amino acid uptake have been well characterized in mammalian cells (12-15). The L-system transports amino acids with rings or branches on their side chains, such as leucine and phenylalanine, is transstimulated by intracellular L-system amino acids, and is insensitive to the sodium gradient across the plasma membrane. L-system transport is characterized by the system specific synthetic amino acid, 2-amino-2carboxy-bicyclo(2,2,1)-heptane (BCH) (14). The A-system transports neutral amino acids with short, polar, or linear side chains, is transinhibited by intracellular A-system amino acids, and is dependent on the transmembrane sodium gradient. The synthetic amino acid, 2-(methylamino) isobutyric acid (methyl-AIB) is transported selectively by the A-system and is used to characterize this pathway. The ASC-system transports alanine, serine, and cysteine, and is also dependent on the transmembrane sodium gradient.

Measurement of amino acid uptake. Lymphocytes were removed from culture at the required times, washed twice in HBSS, and resuspended at a concentration of $1 \times 10^{7}$ cells $/ \mathrm{ml}$ in HBSS containing $1 \%$ $\mathrm{wt} /$ vol BSA, pH 7.45. The cell volume and cell water were determined as published previously (16), and cell viability was assessed by fluorescent microscopy using propidium iodide and acridine orange (17). Cell viability was $>90 \%$ in all experiments. Cells were preincubated at $37^{\circ} \mathrm{C}$ for $30 \mathrm{~min}$ in $1-\mathrm{ml}$ aliquots to deplete the intracellular amino acid stores (4), and uptake was initiated by adding $0.5 \mu \mathrm{Ci} / \mathrm{ml}$ of ${ }^{14} \mathrm{C}$-labeled amino acid with sufficient carrier to provide amino acid concentrations from 0.05 to $4.0 \mathrm{mM}$. Uptake was measured for 0.5 min with $\mathrm{BCH}$ and leucine and for $1.0 \mathrm{~min}$ with methyl-AIB. Samples were removed from the incubation medium at the required time, chilled, and rapidly separated from the suspending medium through a butyl phthalate/corn oil gradient (4). Uptake is known to be linear during the time periods measured, enabling the calculation of the initial velocity of amino acid transport, $V_{\mathrm{i}}$, from the formula: $V_{\mathrm{i}}$ $=d\left[\left(A_{i} / A_{e}\right)\right] / d \mathrm{t} \times C_{\text {outside }}$, where $A_{i}$ and $A_{e}$ represent the intracellular and extracellular radioactivity per unit volume of water. $C_{\text {outside }}$ is the micromolar concentration of amino acid in the incubation medium; $V_{\mathrm{i}}$ is expressed as micromoles per liter cell water per minute. The values for $V_{\mathrm{i}}$ were calculated using the cell volume observed at each time point of the experiments.

Calculation of the kinetics of amino acid uptake. A computerized multicomponent analysis was used to analyze the kinetic parameters of amino acid uptake as described previously (13). The experimental values for $V_{\mathrm{i}}$ reflect the sum of two uptake processes: a saturable, carrier-mediated process that follows Michaelis-Menten kinetics and a nonsaturable process related to the transmembrane concentration gradient. The values for $K_{\mathrm{m}}, V_{\max }$, and constant for nonsaturable uptake, $K_{\mathrm{u}}$, that best fit the observed data are calculated by a nonlinear leastsquares analysis:

$$
S=\Sigma\left[V(n)-\left.\left\{\frac{V_{\max }}{\left[K_{\mathrm{m}} / C_{\text {out }}(n)\right]+1}+K_{\mathrm{u}}\left[C_{\text {out }}(n)-C_{\mathrm{in}}(n)\right]\right\}\right|^{2},\right.
$$

where $S$, the sum of the squared residuals, is minimized. The measured velocity, $V(n)$, reflects the value obtained at the nth external and internal amino acid concentrations, $C_{\text {out }}(n)$ and $C_{\text {in }}(n)$, respectively.

Statistical methods. Amino acid transport velocities of untreated and TPA-treated samples were compared using a paired, two-tailed $t$ test.

Cell morphology and cytoplasmic immunoglobulin. CLL B lymphocytes were removed from culture after $40 \mathrm{~h}$, washed twice in HBSS, resuspended in TC-199 with $1 \%$ BSA, and cytocentrifuged onto microscope slides. Cell morphology was evaluated by light microscopy after standard Wright-Giemsa staining. Cytoplasmic immunoglobulin production was evaluated by observing the increase in fluorescein-labeled anti-human Ig antibody binding to cells treated with TPA as compared with untreated cells. Cytocentrifuged samples were fixed and permeabilized in cold acetone for $10 \mathrm{~min}$ followed by incubation with $50 \mu \mathrm{l}$ of a 1:10 dilution of anti-Ig (Cooper Biomedical, Inc., Malvern, PA) for $30 \mathrm{~min}$ at room temperature in a humidified chamber. Nonbound antibody was washed free with phosphate-buffered saline, and intensity of fluorescence was determined using a Nikon Fluophot microscope. Bone marrow plasma cells from a patient with myeloma were used as a positive control, and fluorescein-conjugated anti-rat $\mathrm{C}_{3}$ (Cooper Biomedical, Inc.) was used as a control for nonspecific binding.

\section{Results}

TPA effect on L-system transport in CLL B lymphocytes. The $V_{\mathrm{i}}$ of L-system amino acid uptake in TPA-treated CLL B lymphocytes was assessed with $0.1 \mathrm{mM} \mathrm{BCH}$, an L-system specific amino acid (14). Values obtained after 2,16 , and $40 \mathrm{~h}$ incubation with $0.15 \mu \mathrm{M}$ TPA are shown for five populations of CLL lymphocytes in Table II. The mean $V_{i}$ for untreated cells 
Table II. L-System Transport in CLL B Lymphocytes Treated with TPA

\begin{tabular}{|c|c|c|c|c|c|c|c|}
\hline \multirow{3}{*}{$\begin{array}{l}\text { Experiment } \\
\text { no. }\end{array}$} & \multirow[b]{3}{*}{ Patient } & \multicolumn{6}{|c|}{ Initial velocity of $\mathrm{BCH}$ uptake } \\
\hline & & \multicolumn{3}{|c|}{ Untreated } & \multicolumn{3}{|c|}{ TPA treated } \\
\hline & & $2 \mathrm{~h}$ & $16 \mathrm{~h}$ & $40 \mathrm{~h}$ & $2 \mathrm{~h}$ & $16 \mathrm{~h}$ & $40 \mathrm{~h}$ \\
\hline 1 & V.P. & 102 & 127 & 101 & 89 & 1,103 & 3,122 \\
\hline 2 & A.C. & 59 & 93 & 90 & 42 & 488 & 698 \\
\hline 3 & Ni.Di. & 58 & 196 & 121 & ND & 1,437 & 1,938 \\
\hline 4 & A.B. & 91 & 180 & 237 & 60 & 1,658 & 2,540 \\
\hline 5 & M.M. & 54 & 134 & 154 & 39 & 1,250 & 1,674 \\
\hline Mean \pm SE & & $73 \pm 10$ & $146 \pm 19$ & $141 \pm 27$ & $58 \pm 12$ & $1,187 \pm 198$ & $1,994 \pm 416$ \\
\hline
\end{tabular}

The L-system was assessed by measuring the uptake of the L-system specific amino acid, BCH, at $0.1 \mathrm{mM}$. The initial velocity of transport was determined after incubation with TPA $(0.15 \mu \mathrm{M})$ for the indicated time periods. The $V_{\mathrm{i}}$ is expressed as micromoles per liter cell water per minute. ND, Not done.

showed a modest change in magnitude, with increasing length of incubation from $73 \mu \mathrm{mol} / \mathrm{liter}$ cell water per minute at $2 \mathrm{~h}$ to $141 \mu \mathrm{mol} /$ liter cell water per minute $(P<0.05)$ at $40 \mathrm{~h}$. The mean $V_{\mathrm{i}}$ for TPA-treated cells at $2 \mathrm{~h}, 58 \mu \mathrm{mol} / \mathrm{liter}$ cell water per minute, was similar to untreated cells after $2 \mathrm{~h}$ of incubation. A twofold increase in the $V_{\mathrm{i}}$ was noted in TPA treated cells as compared with untreated cells after a 9-h exposure. However, marked enhancement of L-system transport was seen after incubation with TPA for 16 and $40 \mathrm{~h}$ in each experiment. The mean uptake of $\mathrm{BCH}$ was eight times greater in TPA-treated CLL cells, $1,187 \mu \mathrm{mol} /$ liter cell water per minute, after a 16-h incubation, and increased 14-fold to $1,994 \mu \mathrm{mol} /$ liter cell water per minute after incubation for $40 \mathrm{~h}$. The degree of enhancement in individual experiments ranged from an 8-fold to a 31-fold increase in transport after $40 \mathrm{~h}$ of incubation in TPA.

The relationship of L-system enhancement to TPA concentration is illustrated in Fig. 1. There was a modest enhancement of BCH transport at 16 and $40 \mathrm{~h}$ in CLL cells exposed to DMSO alone and to TPA at a concentration of $0.0005 \mu \mathrm{M}$. Marked transport enhancement was noted at TPA concentrations $\overline{\overline{ }} 0.005 \mu \mathrm{M}$, and was maximal between 0.05 and $0.5 \mu \mathrm{M}$. In all other experiments, $0.15 \mu \mathrm{M}$ TPA was used, which produced a maximal increment in transport.

The TPA-induced enhancement of L-system transport paralleled the cell maturation induced by this agent in CLL B lymphocytes (5-7). Morphologic changes were seen in $70 \%$ of TPA-treated cells at $40 \mathrm{~h}$ and included an increase in cell volume, an increase in nuclear parachromatin, the reappearance of nucleoli, an eccentric location of the nucleus, and an increase in cytoplasmic volume with multiple thin cytoplasmic projections (Fig. 2). In contrast, untreated cells contained only 2 and $7 \%$ large lymphocytes at 0 and $40 \mathrm{~h}$, respectively. Cell volume increased in TPA-treated CLL cells from a mean of $204 \mathrm{fl} /$ cell at $2 \mathrm{~h}$ to $255 \mathrm{fl} /$ cell at $40 \mathrm{~h}$, while untreated cells did not increase in volume over $40 \mathrm{~h}$ (Fig. 3). Increased cytoplasmic immunoglobulin was detected at $40 \mathrm{~h}$ in TPA-treated cells of three of the five patients tested using a fluorescein-labeled anti-Ig antibody. These changes are characteristic of TPA-induced maturation of CLL B lymphocytes (5-7).

TPA effect on L-system transport kinetics in CLL B lymphocytes. The L-system transport $V_{\max }$ of fresh CLL B lymphocytes is $10 \%$ of that observed in normal blood B lympho- cytes (4). The $V_{\max }$, the affinity constant $\left(K_{\mathrm{m}}\right)$, and the constant describing nonsaturable transport $\left(K_{\mathrm{u}}\right)$ were determined in CLL B lymphocytes after incubation without and with TPA for $16 \mathrm{~h}$. A multicomponent analysis was used to separate transport into a saturable carrier-mediated process and a nonsaturable process related to the transmembrane concentration gradient (13). Fig. 4 shows the relationship of the velocity of $\mathrm{BCH}$ uptake to external $\mathrm{BCH}$ concentration for a representative experiment. The solid lines represent the nonlinear leastsquares fitted curves for total $\mathrm{BCH}$ uptake, and the dashed lines represent saturable carrier-mediated transport. The $V_{\max }$ of saturable transport increased from $139 \mu \mathrm{mol} / \mathrm{liter}$ cell water per minute in untreated cells to 963 in TPA-treated cells. This marked enhancement of saturable $\mathrm{BCH}$ uptake represents an increased capacity of the L-amino acid transport system.

Results of five individual experiments are shown in Table

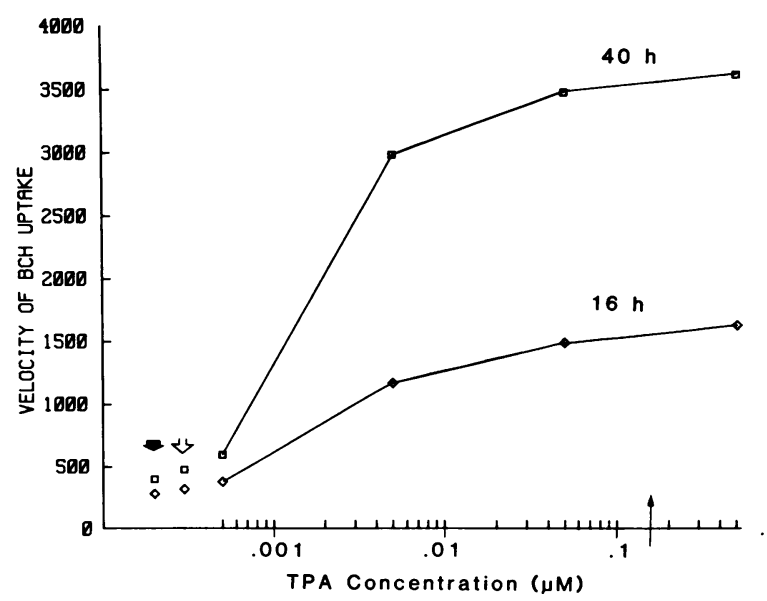

Figure 1. Initial velocity of $\mathrm{BCH}$ uptake by CLL B lymphocytes in the presence of no additive (solid arrow), $0.05 \%$ DMSO (open arrow), and increasing concentrations of TPA. The initial velocity of transport was determined after incubation for $16 \mathrm{~h}$ (diamonds) and $40 \mathrm{~h}$ (squares). TPA was present at the indicated concentrations from the beginning of the incubation. The $V_{\mathrm{i}}$ is expressed as micromoles per liter cell water per minute. Values are the means of duplicate determinations in a single experiment in which the standard errors did not exceed $4 \%$. The thin arrow at $0.15 \mu \mathrm{M}$ indicates the TPA concentration used in all other experiments. 

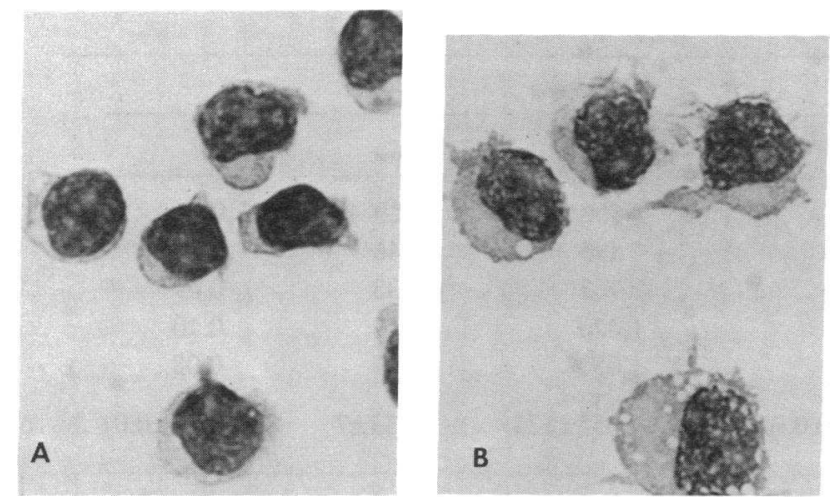

Figure 2. Wright-Giemsa stained CLL B lymphocytes after a 40-h incubation without $(A)$ or with $(B)$ TPA $(0.15 \mu \mathrm{M})$. Untreated cells resemble fresh CLL B lymphocytes. TPA-treated cells have an increase in cell volume, an altered nuclear appearance with increased parachromatin and visible nucleoli, eccentric location of the nucleus, and increased cytoplasm with multiple thin cytoplasmic projections. Original, $\times 1,000$.

III. The mean $V_{\max }$ for untreated CLL cells was $200 \mu \mathrm{mol} / \mathrm{liter}$ cell water per minute after the 16-h incubation. TPA treatment increased the $V_{\max }$ fivefold to $1,055 \mu \mathrm{mol} /$ liter cell water per minute $(P<0.01)$. There was a shift in the $K_{\mathrm{m}}$ from a mean of $156 \mu \mathrm{mol} /$ liter to $33 \mu \mathrm{mol} /$ liter $(P=0.05)$, suggesting an increase in L-system transport substrate affinity after TPA treatment. There was a small increase in the $K_{\mathrm{u}}$ for $\mathrm{BCH}$, from 0.07 to $0.10 \mathrm{~min}^{-1}(P<0.10)$, although this effect did not account for the marked enhancement in $\mathrm{BCH}$ transport (Fig. 4).

TPA effect on L-system transport in normal B lymphocytes. The $V_{\mathrm{i}}$ of $\mathrm{BCH}$ uptake was determined in normal blood $\mathrm{B}$ lymphocytes after incubation with or without TPA for $12 \mathrm{~h}$. The $V_{\mathrm{i}}$ of $0.1 \mathrm{mM} \mathrm{BCH}$ was $300 \mu \mathrm{mol} /$ liter cell water per

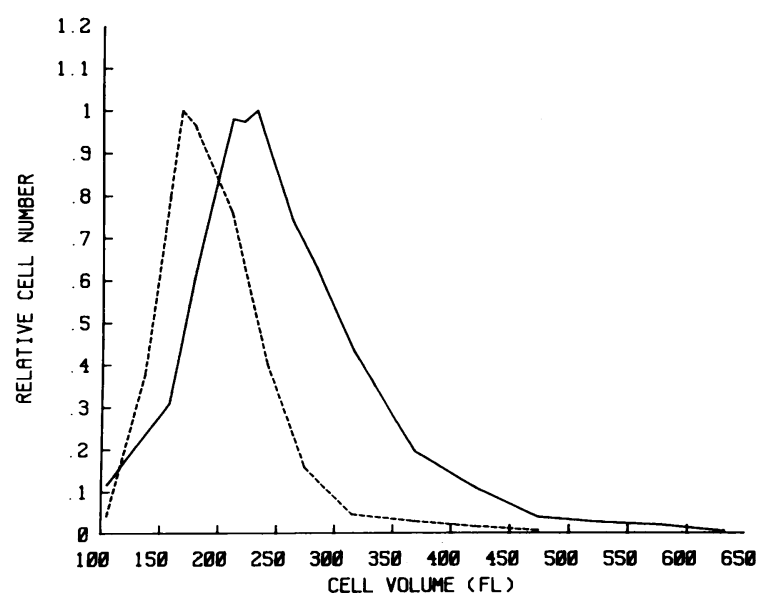

Figure 3. Cell volume distribution of CLL B lymphocytes after 40-h incubation at $37^{\circ} \mathrm{C}$ without (dashed line) and with (solid line) 0.15 $\mu \mathrm{M}$ TPA. Cell volume was determined using an electronic cell counter (model ZBI; Coulter Electronics Inc.) equipped with a channelyzer (Coulter Electronics Inc.). A computer program, Accu Comp C/1000 (Coulter Electronics Inc.), was used for calibration based on lymphocyte deformability and counting solution tonicity (16). Data shown are from experiment 4 of Table II and are expressed as femtoliters per cell.

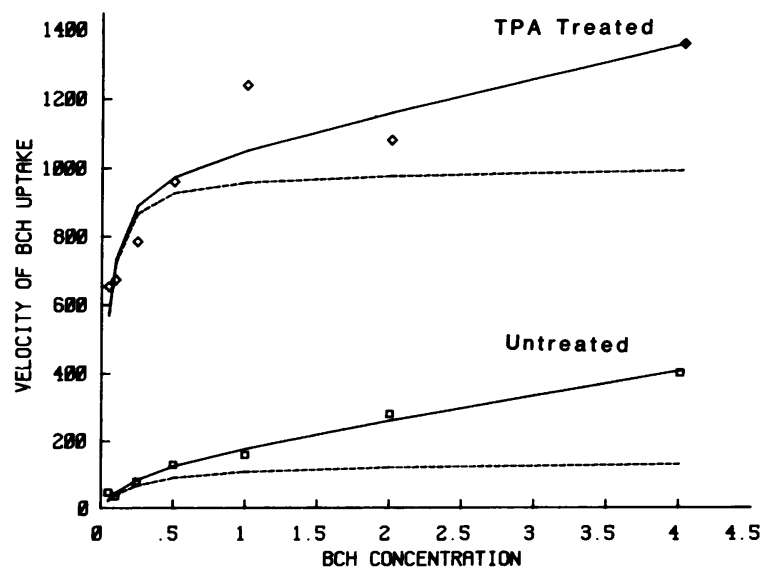

Figure 4. Initial velocity of BCH uptake by CLL B lymphocytes at increasing concentrations of external $\mathrm{BCH}$ determined after a 16-h incubation without or with TPA $(0.15 \mu \mathrm{M})$. The observed measurements of $\mathrm{BCH}$ uptake at $\mathrm{BCH}$ concentrations from 0.05 to $4.0 \mathrm{mM}$ are expressed in micromoles per liter cell water per minute and are indicated by the squares (untreated cells) and diamonds (TPAtreated cells). A multicomponent analysis was used to separate the rate of amino acid uptake into a carrier-mediated process that obeys Michaelis-Menten kinetics and a nonsaturable process related to the transmembrane concentration gradient. The solid lines through the points are the fitted curves for total $\mathrm{BCH}$ uptake, and the dashed lines indicate carrier-mediated transport.

minute in untreated $B$ lymphocytes and increased threefold to 1,027 in B cells treated with TPA $(P<0.01)$ (Table IV). A less pronounced enhancement was seen at $5.1 \mathrm{mM} \mathrm{BCH}$, with a mean $V_{\mathrm{i}}$ of 1,360 in untreated $B$ lymphocytes and 1,700 in TPA-treated B cells $(P>0.10)$ (Table IV). Mean cell volume at $12 \mathrm{~h}$ was $192 \mathrm{fl} /$ cell without TPA treatment and $233 \mathrm{fl} / \mathrm{cell}$ with TPA.

A full kinetic analysis of L-system transport in TPA-treated normal B lymphocytes was not possible due to the limited number of cells available after purification. However, an estimate of the $V_{\max }$ after $12 \mathrm{~h}$ of TPA treatment was calculated as $1,190 \mu \mathrm{mol} / \mathrm{liter}$ cell water per minute using the $V_{\mathrm{i}}$ at $5.1 \mathrm{mM}$ $\mathrm{BCH}$ and the diffusion constant of $0.1 \mathrm{~min}^{-1}$ obtained with both TPA-treated CLL B cells and normal T lymphocytes (13). This is similar to the $V_{\max }$ of TPA-treated CLL B cells at $16 \mathrm{~h}$ $(1,055 \mu \mathrm{mol} /$ liter cell water per minute) and suggests that TPA-treated CLL B cells have the same L-system transport characteristics as TPA-treated normal B lymphocytes.

TPA effect on leucine transport in CLL and normal $B$ lymphocytes. The L-system is the primary transport carrier for the naturally occurring amino acid, leucine, in normal blood B lymphocytes, and leucine uptake is diminished in resting CLL B lymphocytes due to the low L-system activity. The $V_{\max }$ for leucine uptake is $450 \mu \mathrm{mol} /$ liter cell water per minute in CLL B cells as opposed to 1,686 in normal blood B cells and 1,240 in normal blood T cells (4). Much of the existing leucine uptake in CLL B cells occurs due to compensatory transport by the ASC-system (4).

TPA treatment for $12 \mathrm{~h}$ resulted in a fourfold increase in the total $V_{\mathrm{i}}$ for $0.1 \mathrm{mM}$ leucine in CLL B lymphocytes from a mean of $279 \mu \mathrm{mol} /$ liter cell water per minute in untreated cells to 1,123 in TPA-treated cells (Table V). The total $V_{\mathrm{i}}$ for 0.1 $\mathrm{mM}$ leucine in normal blood B lymphocytes was $387 \mu \mathrm{mol} /$ 
Table III. L-System Kinetic Parameters in CLL B Lymphocytes Treated with TPA

\begin{tabular}{|c|c|c|c|c|c|c|c|}
\hline \multirow{2}{*}{$\begin{array}{l}\text { Experiment } \\
\text { no. }\end{array}$} & \multirow[b]{2}{*}{ Patient } & \multicolumn{3}{|l|}{ Untreated } & \multicolumn{3}{|l|}{ TPA treated } \\
\hline & & $V_{\max }$ & $K_{\mathrm{m}}$ & $K_{\mathrm{u}}$ & $V_{\max }$ & $K_{\mathrm{m}}$ & $K_{\mathrm{u}}$ \\
\hline 1 & M.M. & 180 & 63 & 0.10 & 1,660 & 29 & 0.16 \\
\hline 2 & J.Mi. & 73 & 102 & 0.06 & 580 & 46 & 0.05 \\
\hline 3 & J.B. & 139 & 271 & 0.07 & 963 & 33 & 0.09 \\
\hline 4 & J.Me. & 351 & 148 & 0.08 & 1,020 & 11 & 0.10 \\
\hline 5 & V.P. & 257 & 198 & 0.03 & 1,050 & 47 & 0.08 \\
\hline Mean \pm SE & & $200 \pm 48$ & $156 \pm 36$ & $0.07 \pm 0.02$ & $1,055 \pm 173$ & $33 \pm 7$ & $0.10 \pm 0.01$ \\
\hline
\end{tabular}

The kinetics of L-system transport were assessed by measuring the uptake of the L-system specific amino acid, BCH, at concentrations of $0.05-4 \mathrm{mM}$. The $V_{\mathrm{i}}$ at each concentration was determined after incubation with TPA $(0.15 \mu \mathrm{M})$ for $16 \mathrm{~h}$. The $V_{\max }$ is expressed as micromoles per liter cell water per minute, the $K_{\mathrm{m}}$ as micromoles per liter. The $K_{\mathrm{u}}$ is expressed as minute ${ }^{-1}$.

liter cell water per minute in untreated cells and increased to 1,024 in TPA-treated cells (Table V).

To determine the proportion of the enhanced leucine uptake mediated specifically by the L-system, transport of $\left[{ }^{14} \mathrm{C}\right]-$ leucine was measured in the presence of a 50 -fold excess of unlabeled $\mathrm{BCH}$, an amino acid transported only by the L-system. Excess $\mathrm{BCH}$ inhibited $>90 \%$ of $\left[{ }^{14} \mathrm{C}\right] \mathrm{BCH}$ uptake in untreated and TPA-treated cells as would be expected (data not shown). Eiscess $\mathrm{BCH}$ inhibited $88 \%$ of $0.1 \mathrm{mM}$ leucine uptake in CLL B cells treated with TPA for $12 \mathrm{~h}$ as compared with only $36 \%$ inhibition in untreated cells, indicating that the enhanced portion of leucine transport in TPA-treated CLL B lymphocytes was mediated by the L-system (Table V).

The L-system specific $V_{\mathrm{i}}$ for leucine was calculated from the product of the total $V_{\mathrm{i}}$ for leucine and the percent inhibition of uptake by excess BCH. The L-system specific $V_{\mathrm{i}}$ for 0.1 $\mathrm{mM}$ leucine in CLL B cells was $100 \mu \mathrm{mol} / \mathrm{liter}$ cell water per minute, or $39 \%$ of the $V_{\mathrm{i}}$ in normal B cells, $259 \mu \mathrm{mol} / \mathrm{liter}$ cell water per minute (Table V). TPA treatment caused an increase in the L-system specific $V_{\mathrm{i}}$ in both CLL and normal $\mathrm{B}$ cells. The $V_{\mathrm{i}}$ for CLL B cells increased 10-fold to 988 and the $V_{\mathrm{i}}$ for normal B cells increased 3-fold to 901 (Table V). The L-system specific $V_{\mathrm{i}}$ for leucine in TPA-treated CLL B lymphocytes was similar to that of TPA-treated normal B lymphocytes at a physiological leucine concentration of $0.1 \mathrm{mM}$.

Cycloheximide effect on L-system transport in CLL B lymphocytes. The enhanced L-system transport in CLL cells that followed TPA treatment may have required protein synthesis, since the effect was not seen after a 2-h exposure to TPA, and

Table IV. BCH Transport in Normal Blood B Lymphocytes Treated with TPA

\begin{tabular}{lrl}
\hline $\begin{array}{l}\mathrm{BCH} \\
\text { concentration }\end{array}$ & Untreated & TPA treated \\
\hline$m M$ & & \\
0.1 & $300 \pm 18(6)$ & $1,027 \pm 75(6)$ \\
5.1 & $1,360 \pm 136(3)$ & $1,700 \pm 68(3)$
\end{tabular}

The $V_{\mathrm{i}}$ of the L-system specific amino acid, $\mathrm{BCH}$, was determined after incubation with TPA $(0.15 \mu \mathrm{M})$ for $12 \mathrm{~h}$. The $V_{\mathrm{i}}$ is expressed as the mean $\pm \mathrm{SE}$ of $(N)$ lymphocyte populations in micromoles per liter cell water per minute. the transport rate increased further from 16 to $40 \mathrm{~h}$ (Table II). To test this possibility, CLL B lymphocytes were incubated with or without cycloheximide, $100 \mu \mathrm{g} / \mathrm{ml}$, for $12 \mathrm{~h}$, which was a concentration that we established inhibited $>90 \%$ of $\left[{ }^{14} \mathrm{C}\right]-$ leucine incorporation into cellular protein in TPA-treated cells. Cycloheximide treatment reduced the L-system $V_{\mathrm{i}}$ of CLL cells not exposed to TPA in separate experiments from 141 and $144 \mu \mathrm{mol} /$ liter cell water per minute to 104 and 85 , respectively, a $34 \%$ mean inhibition (Table VI). Moreover, cycloheximide treatment decreased the L-system $V_{\mathrm{i}}$ in TPAtreated cells from 1,317 and $936 \mu \mathrm{mol} /$ liter cell water per minute to 107 and 90 , a $91 \%$ mean inhibition (Table VI). The $V_{\mathrm{i}}$ for CLL cells exposed to both TPA and cycloheximide was identical to that for CLL cells exposed to cycloheximide alone (Table VI). CLL cells exposed to TPA for $12 \mathrm{~h}$ followed by cycloheximide exposure for 30 min showed no inhibition of L-system transport, indicating that cycloheximide did not directly inhibit the $\mathrm{L}$-amino acid transport system.

TPA effect on A-system transport in CLL B lymphocytes. A-system amino acid transport was assessed using the A-system specific synthetic amino acid, 2-(methylamino) isobutyric acid (methyl-AIB, $0.1 \mathrm{mM}$ ). The $V_{\mathrm{i}}$ of fresh CLL B cells unexposed to TPA was $22 \mu \mathrm{mol} / \mathrm{liter}$ cell water per minute, which is

Table V. Leucine Transport in CLL and Normal Blood B Lymphocytes Treated with TPA

\begin{tabular}{lcl}
\hline & Untreated & TPA treated \\
\hline CLL B lymphocytes & & \\
Total $V_{\mathrm{i}}$ & $279 \pm 35(3)$ & $1,123 \pm 308(3)$ \\
$\%$ inhibition by BCH & $36 \pm 12(3)$ & $88 \pm 1.4(3)$ \\
L-system specific $V_{\mathrm{i}}$ & $100(3)$ & $988(3)$ \\
Normal B lymphocytes & & \\
Total $V_{\mathrm{i}}$ & $387 \pm 18(3)$ & $1,024 \pm 229(3)$ \\
\% inhibition by BCH & 62,72 & 88,87 \\
L-system specific $V_{\mathrm{i}}$ & $259(3)$ & $901(3)$
\end{tabular}

The $V_{\mathrm{i}}$ of the naturally occurring amino acid, leucine, was assessed at $0.1 \mathrm{mM}$ after incubation with TPA $(0.15 \mu \mathrm{M})$ for $12 \mathrm{~h}$. The L-system specific $V_{\mathrm{i}}$ for leucine was calculated from the product of the total $V_{\mathrm{i}}$ and the percent inhibition of uptake by a 50 -fold excess of the L-system specific amino acid, $\mathrm{BCH}$. The total $V_{\mathrm{i}}$ and the $\mathrm{L}$-system specific $V_{\mathrm{i}}$ are expressed as micromoles per liter cell water per minute. The number of cell populations is shown in parentheses. 
Table VI. Inhibition of L-System Transport by Cycloheximide in CLL B Lymphocytes Treated with TPA

\begin{tabular}{lll}
\hline & Untreated & TPA treated \\
\hline Control & 141,144 & $1,317,936$ \\
Cycloheximide & 104,85 & 107,90 \\
Mean inhibition & $34 \%$ & $91 \%$
\end{tabular}

The $V_{\mathrm{i}}$ of L-system transport was assessed by measuring the uptake of the L-system specific amino acid, BCH, at a concentration of 0.1 $\mathrm{mM}$. Transport was measured after incubation with either TPA $(0.15$ $\mu \mathrm{M})$, cycloheximide $(100 \mu \mathrm{g} / \mathrm{ml})$, or both for $12 \mathrm{~h}$. The $V_{\mathrm{i}}$ is expressed as micromoles per liter cell water per minute. Cycloheximide inhibited $91 \%$ of $\left[{ }^{14} \mathrm{C}\right]$ leucine incorporation into cellular protein in the TPA-treated cells.

similar to the $V_{\mathrm{i}}$ found in normal human B lymphocytes, 15 $\mu \mathrm{mol} / \mathrm{liter}$ cell water per minute (4). In contrast to TPA-induced L-system enhancement, TPA treatment resulted in a rapid induction of enhanced A-system transport in CLL B lymphocytes, with mean initial velocities of 47,55 , and 84 after $0.5,2$, and $12 \mathrm{~h}$ of incubation with TPA, respectively (four experiments).

\section{Discussion}

TPA treatment increased the low level of uptake of L-system amino acids in CLL B lymphocytes by increasing the activity of the L-system transporter. Four lines of evidence support this contention. First, the enhanced $\mathrm{BCH}$ transport exhibited the saturation kinetics of a transport carrier protein and represented an increase in carrier capacity. Second, after $16 \mathrm{~h}$ of TPA treatment, the $V_{\max }$ of L-system transport in CLL cells was similar to that of TPA-treated normal B lymphocytes. Third, the proportion of leucine uptake that occurred via the L-system increased with TPA treatment, and fourth, the magnitude of L-system specific leucine transport in TPA-treated CLL cells was similar to that of TPA-treated normal B lymphocytes.

After TPA treatment, the L-system transporter in CLL B lymphocytes had an apparent increased affinity for $\mathrm{BCH}$. Heightened affinity for A-system amino acids has been observed previously in CLL B lymphocytes as the cells adapted to an amino acid-deficient environment (18). Adaptive A-system transport has been described in many cell types, and it has been suggested that a new species of carrier for A-system substrates may be synthesized in a milieu with a low amino acid concentration (18). The reason for the increased affinity of the L-system for BCH in TPA-treated CLL cells is unclear. However, the markedly enhanced transport of $0.1 \mathrm{mM} \mathrm{BCH}$ in TPA-treated normal B lymphocytes suggests the presence of a high affinity L-system transporter in these cells as well.

The biologic response to phorbol esters in lymphocytes and other cell types is thought to result from direct activation of the calcium-dependent enzyme, protein kinase $C$, with resultant phosphorylation and activation of either intermediary or response proteins (19-21). Several TPA-induced biological responses are rapid, such as superoxide production in human monocytes (22) and $\mathrm{Na}^{+} / \mathrm{H}^{+}$exchange in rat thymic lymphocytes (23). We found that TPA-induced enhancement of Asystem amino acid uptake in CLL cells occurred after $30 \mathrm{~min}$ of incubation with TPA. Increased transport of neutral amino acids in bovine tonsillar lymphocytes (24) and rat thymic lymphocytes (23) also occurred within $30 \mathrm{~min}$ of TPA exposure, and the rapid effect in rat thymocytes was felt to be the result of direct phosphorylation of existing transport proteins (23). In contrast, no increased L-system amino acid transport was observed in CLL B lymphocytes after a 2-h incubation with TPA. Furthermore, the cycloheximide-sensitive L-system enhancement measured at 16 and $40 \mathrm{~h}$ is compatible with a requirement for new protein synthesis to restore L-system transport function in the B lymphocytes of CLL. TPA may be activating an intracellular signal to enhance L-system transport that persists after potential down-regulation or degradation of protein kinase $C$ over the $40-h$ period of observation.

The fundamental reason for the low L-system transport in CLL B lymphocytes is unclear. Our prior studies of L-system uptake by several normal and neoplastic lymphocyte types including T cell CLL (Sézary syndrome) have confirmed the uniqueness of the low L-system transport by $\operatorname{CLL} B$ cells $(3,4)$. Cells expressing early and intermediate B lymphocyte phenotypes have recently been identified in normal human lymph nodes (25) and fetal spleen (26), but they have not been isolated in sufficient quantity and purity to study amino acid transport. We believe it improbable that CLL B cells have an order of magnitude decrease in L-system transport as an expression of cell immaturity. The fundamental importance of amino acid acquisition for the heightened protein synthesis and metabolism of young, proliferative, maturing cells would argue against such a profound decrease in uptake in immature but otherwise normal cells.

There is precedent for chemical additives correcting the maturation block of neoplastic cells and, in the process, permitting the expression of a more normal phenotype. The ability of the HL-60 progranulocytic leukemia cell line to complete maturation to neutrophilic segmented granulocytes in the presence of DMSO or to macrophages in the presence of phorbol esters is well documented $(27,28)$. We believe the effect of TPA on CLL L-system transport is analogous, since its increased capacity closely parallels the induction of a phenotype that is characteristic of later cells in the B cell lineage (e.g., plasma cells).

\section{Acknowledgments}

We are grateful to Dr. Daniel Ryan for assistance with flow cytometry and to Carol Pearce for assistance in preparation of the manuscript.

This work was supported by U.S. Public Health Service research grants CA34691, CA12790, and training grant HL-07152, and by the University of Rochester Pediatric Blood Research "Jimmy Fund." Dr. Woodlock is a James P. Wilmont Cancer Research Fellow.

\section{References}

1. Gale, R. P., and K. A. Foon. 1985. Chronic lymphocytic leukemia: recent advances in biology and treatment. Ann. Intern. Med. 103:101-120.

2. LaMantia, K., M. Conklyn, F. Quagliata, and R. Silber. 1977. Lymphocyte 5'-nucleotidase: absence of detectable protein in chronic lymphocytic leukemia. Blood. 50:683-689.

3. Segel, G. B., and M. A. Lichtman. 1982. Decreased L-system for amino acid transport in chronic lymphocytic leukemic lymphocytes. $J$. Biol. Chem. 257:9255-9257. 
4. Segel, G. B., W. Simon, and M. A. Lichtman. 1984. Multicomponent analysis of amino acid transport in human lymphocytes: diminished L-system transport in chronic leukemic B lymphocytes. $J$. Clin. Invest. 74:17-24.

5. Totterman, T. H., K. Nilsson, and C. Sundstrom. 1980. Phorbol ester-induced differentiation of chronic lymphocytic leukemia cells. Nature (Lond.). 288:176-178.

6. Okamura, J., M. Letarte, L. D. Stein, N. H. Sigal, and E. W. Gelfand. 1982. Modulation of chronic lymphocytic leukemia cells by phorbol ester: increase in Ia expression, IgM secretion and MLR stimulatory capacity. J. Immunol. 128:2276-2280.

7. Gordon, J., H. Mellstedt, P. Aman, P. Biberfeld, and G. Klein. 1984. Phenotypic modulation of chronic lymphocytic leukemia cells by phorbol ester: induction of IgM secretion and changes in the expression of B cell associated surface antigens. J. Immunol. 132:541547.

8. Segel, G. B., D. H. Ryan, and M. A. Lichtman. 1985. Ecto-nucleotide triphosphatase activity of human lymphocytes: studies of normal and CLL lymphocytes. J. Cell. Physiol. 124:424-432.

9. Segel, G. B., M. A. Lichtman, B. R. Gordon, J. L. MacPherson, and J. Nusbacher. 1976. Plateletpheresis residues: a source of large quantities of human blood lymphocytes. Transfusion. 16:455-459.

10. Scully, S. P., G. B. Segel, and M. A. Lichtman. 1982. Plasma membrane vesicles prepared from unadhered monocytes: characterization of calcium transport and the calcium ATPase. Cell Calcium. 3:515-530.

11. Handwerger, B. S., and R. H. Schwartz. 1974. Separation of murine lymphoid cells using nylon wool columns. Transplantation. 18:544-547.

12. Segel, G. B., and M. A. Lichtman. 1981. Amino acid transport in human lymphocytes: distinctions in the enhanced uptake with PHA treatment or amino acid deprivation. J. Cell. Physiol. 106:303-308.

13. Segel, G. B., W. Simon, and M. A. Lichtman. 1983. A multicomponent analysis of amino acid transport systems in human lymphocytes. 1. Kinetic parameters of the A and $L$ systems and pathways of uptake of natural occurring amino acids in blood lymphocytes. $J$. Cell. Physiol. 116:372-378.

14. Christensen, H. N., M. E. Handlogten, I. Lam, H. S. Tager, and R. Zand. 1969. A bicyclic amino acid to improve discriminations among transport systems. J. Biol. Chem. 244:1510-1520.

15. Guidotti, G. G., A. F. Borghetti, and G. C. Gazzola. 1978. The regulation of amino acid transport in animal cells. Biochim. Biophys. Acta. 515:329-366.
16. Segel, G. B., G. R. Cokelet, and M. A. Lichtman. 1981. The measurement of lymphocyte volume: importance of reference particle deformability and counting solution tonicity. Blood. 57:894-899.

17. Parks, D. R., V. M. Bryan, V. M. Oi, V. T. Oi, and L. A. Herzenberg. 1979. Antigen specific identification and cloning of hybridomas with a fluorescence activated cell sorter (FACS). Proc. Natl. Acad. Sci. USA. 76:1962-1966.

18. Frengley, P. A., M. A. Lichtman, and W. A. Peck. 1975. Adaptive enhancement of amino acid transport in human leukemic lymphocytes: studies with alpha-aminoisobutyric acid. J. Lab. Clin. Med. 86:984-996.

19. Ashendel, C. L. 1985. The phorbol ester receptor: a phospholipid-regulated protein kinase. Biochim. Biophys. Acta. 822:219-242.

20. Kaibuchi, K., Y. Takai, and Y. Nishizuka. 1985. Protein kinase $\mathrm{C}$ and calcium ion in mitogenic response of macrophage-depleted human peripheral lymphocytes. J. Biol. Chem. 260:1366-1369.

21. Mastro, A. M. 1983. Phorbol ester tumor promoters and lymphocyte proliferation. Cell Biol. Int. Rep. 7:881-893.

22. Costa-Casnellie, M. R., G. B. Segel, and M. A. Lichtman. 1986. Signal transduction in human monocytes: relationship between superoxide production and the level of kinase $\mathrm{C}$ in the membrane. J. Cell. Physiol. 129:336-342.

23. Klip, A., E. Mack, E. J. Cragoe, Jr., and S. Grinstein. 1986. Regulation of amino acid uptake by phorbol esters and hypertonic solutions in rat thymocytes. J. Cell. Physiol. 127:244-252.

24. Kensler, T. W., P. W. Wertz, and G. C. Mueller. 1979. Inhibition of phorbol ester-accelerated amino acid transport in bovine lymphocytes. Biochim. Biophys. Acta. 585:43-52.

25. Caligaris-Cappio, F., M. Gobbi, M. Bofill, and G. Janossy. 1982. Infrequent normal B-lymphocytes express features of B-chronic lymphocytic leukemia. J. Exp. Med. 155:623-628.

26. Antin, J. H., S. G. Emerson, P. Martin, N. Gadol, and K. A. Ault. 1986. Leu-1+ (CD5+) B cells. A major lymphoid subpopulation in human fetal spleen: phenotypic and functional studies. J. Immunol. 136:505-510.

27. Collins, S. J., F. W. Ruscetti, R. E. Gallagher, and R. C. Gallo. 1978. Terminal differentiation of human promyelocytic leukemia cells induced by dimethyl sulfoxide and other polar compounds. Proc. Natl. Acad. Sci. USA. 75:2458-2462.

28. Rovera, G., D. Santoli, and C. Damsky. 1979. Human promyelocytic leukemia cells in culture differentiate into macrophage-like cells when treated with a phorbol diester. Proc. Natl. Acad. Sci. USA. 76:2779-2783. 